\title{
Genetic Insights into Ecological Succession FROM OAK- (QUERCUS ROBUR L.) to Beech- (Fagus sylvatica L.) Dominated Forest Stands
}

\author{
Elzbieta Sandurska, Bartosz Ulaszewski AND JAROslaw BurczyK* \\ Department of Genetics, Institute of Experimental Biology, Faculty of Natural Sciences, \\ Kazimierz Wielki University, Chodkiewicza 30, 85-064 Bydgoszcz, Poland
}

Received December 11, 2016; revision accepted February 15, 2017

\begin{abstract}
Genetic diversity is often considered a major determinant of long term population persistence and its potential to adapt to variable environmental conditions. The ability of populations to maintain their genetic diversity across generations seems to be a major prerequisite for their sustainability, which is particularly important for keystone forest tree species. However, little is known about genetic consequences of demographic alterations occurring during natural processes of ecological succession involving changes in the species composition. Using microsatellites, we investigated genetic diversity of adult and offspring generations in beech (Fagus sylvatica L.) and oak (Quercus robur L.) populations coexisting in a naturally established old-growth forest stand, showing some symptoms of ongoing ecological succession from oak- to beech- dominated forest. In general, adult generations of both species exhibited high levels of genetic diversity ( 0.657 for beech; 0.821 for oak), which, however, depended on the sets of selected genetic markers. Nevertheless, several symptoms such as differences in genetic diversity indices between generations, significant levels of inbreeding (up to 0.029) and low estimates of effective population size (48-80) confirmed the declining status of the oak population. On the other hand, the uniform distribution of genetic diversity indices across generations, low levels of inbreeding (0.004), low genetic differentiation among adults and offspring and, most importantly, large estimates of effective population size (119-716), all supported beech as a successive and successful tree species in the studied forest stand.
\end{abstract}

Keywords: nature reserve, ecological succession, genetic diversity, effective population size, Fagus sylvatica, Quercus robur

\section{INTRODUCTION}

Establishment of protected areas such as nature reserves is one of the major efforts of conservation of terrestrial ecosystems, attempting to protect specific species, habitats or communities (Prendergast et al., 1999). Because nature reserves usually embrace diverse species communities and conserve ecological and evolutionary processes underlying the persistence of such communities, they are considered attractive research objects for studying biological processes existing in fairly undisturbed ecosystems (Soulé, 1985; Balmford et al., 2002).

Long term sustainability of nature reserves is one of the main goals of their conservation (Grumbine, 1994; Bengtsson et al., 2003). However, despite increasing knowledge of ecology (in a broad sense) of terrestrial ecosystems, little is known about the role of genetic diversity of foundation species in the persistence of natural populations (Lande and Shannon, 1996; Hughes et al., 2008). Genetic diversity of keystone tree species is believed to be one of the drivers determining species and genetic diversity of the coexisting communities in forest ecosystems (Whitham et al., 2003, 2006; Gugerli et al., 2013). In temperate zones, forest ecosystems dominated by two or more key-stone tree species are of particular interest, because they may promote greater diversity of coexisting organisms. In this respect, forest stands composed of beech and oak are of particular interest.

Pedunculate oak (Quercus robur L.) and common beech (Fagus sylvatica L.) are among the most important tree species in Central Europe, both from ecological and economical points of view (Packham et al., 2012). Beech and oak form pure and mixed stands, but productivity of mixed beech-oak forests might be superior to pure stands

\footnotetext{
*Corresponding author, email: burczyk@ukw.edu.pl
} 
depending on site conditions (Pretzsch et al., 2013), and the importance of mixed stands might increase with the consequences of climate changes (Pretzsch et al., 2013). However, the future status of beech and oak forests affected by climate changes remains unclear and it is currently under intensive debate (Geßler et al., 2006; Kramer et al., 2010; Czucz et al., 2011; Scharnweber et al., 2011; Mette et al., 2013; Zimmermann et al., 2015). Succession from oak- to beech-dominated forest stands is often observed (Rohner et al., 2012; Petritan et al., 2014), but this process is usually long and complex, involving a variable pattern of competition for light, moisture and nutrient resources at the stage of regeneration, but also a variable pattern of mortality of senescent individuals (Vera et al., 2006; Bontemps et al., 2012; Ligot et al., 2013). However, the role of genetic diversity in the succession process is largely unknown.

Loss of genetic diversity may be an important factor of extinction (Spielman et al., 2004), particularly in isolated populations (Frankham, 2005). However, the loss of genetic diversity in forest tree populations is unlikely, especially in common tree species growing across large areas spanning over continents. Nevertheless, forest management and global climate changes are expected to influence the levels and distribution of genetic diversity of forest trees (Koskela et al., 2007, 2014; Ratnam et al., 2014). The predicted changes in temperature and precipitation regimes might affect particularly broadleaf tree species such as oak and beech (Bussotti et al., 2015).

The extent to which populations can adapt to variable climate conditions and succeed in a competitive environment depends on the within-population genetic diversity and how this diversity is distributed within and among populations (Aitken et al., 2008; Bolte and Degen, 2010). However, one of the major concerns of intensive management of forest tree population is mixing of gene pools from different populations due to long distance commercial seed transfer (Koskela et al., 2014). Such uncontrolled seed movement may lead to establishment of populations maladapted to new environments. Historical seed transfer, extensive particularly in the $19^{\text {th }}$ century, altered the distribution of genetic diversity of several forest trees in Europe (Koskela et al., 2014; Jansen and Geburek, 2016; Myking et al., 2016). It is expected that the exchange of forest reproductive material had a strong impact on the levels of genetic diversity of forest trees and the spatial distribution of genetic diversity, even stronger than natural processes (Geburek and Turok, 2005). Today, natural and introduced populations might be largely intermixed (Konig et al., 2002; Lewandowski et al., 2012, 2014). On the other hand, populations composed of old trees ( $>200$ years old) usually represent native gene pools which may have gene variants and their combinations important for a future success in adaptation to variable (and unpredictable) environmental conditions. Such intact old-growth forest stands, often conserved as nature reserves, are therefore of special interest. Despite the long lifespan of majority of forest trees and their complex age structure, the question remains whether the genetic diversity existing in adult populations is maintained in young, naturally regenerating generations. The maintenance of genetic diversity across generations is considered a major prerequisite for sustainability and persistence of populations of forest trees (Aitken et al., 2008) and is particularly important in nature reserves. This issue becomes fundamental in the context of ecological succession, when one key-stone tree species might be replaced by another. Here, the old-growth forest stands evolving from oak- to beech-dominated forests (Rohner et al., 2012; Petritan et al., 2014) may serve as an excellent study system to investigate genetic aspects of ecological succession.

Here we present a case study focused on genetic diversity of two key-stone tree species (Fagus sylvatica L. and Quercus robur L.) coexisting in a single forest stand showing symptoms of ongoing ecological succession form oak- to beech- dominated forest. Using nuclear microsatellites as genetic markers we investigated the levels of genetic diversity and inbreeding in adult generations, and explored to what extent genetic diversity is transferred to the cohorts of subsequent generations represented by naturally established seedlings. We also performed comparative analyses of effective population sizes. Finally, we provide recommendations for conservation of genetic resources of the studied populations.

\section{METHODS}

The study was conducted in a forest stand being a part of the Jamy Nature Reserve, established in 1968 in the Jamy Forest District in North-Central Poland. In terms of phytosociology, the area is classified as a subcontinental hornbeam forest (TilioCarpinetum) with participation of beech, for which it is the northeastern boundary of the species range. The oldest individuals, according to forest management plans, are at least 218 years old, with a maximum height of 35 meters. For this study the centrally located plot was designed $\left(\varphi 18^{\circ} 56^{\prime} 6.07^{\prime \prime} \mathrm{E}\right.$, $\lambda 53^{\circ} 35^{\prime} 9.67^{\prime \prime} \mathrm{N}$ ) with a round-shaped area of about 5.5 ha. The studied forest stand shows clear symptoms of ecological succession form oak- to beechdominated forest. The oak population is represented only by an even-aged adult cohort (ca. 220 years old) 
and young seedlings, with no individuals at intermediate age classes. On the other hand, the beech population consists of a small fraction (11 ind.) of old trees (DBH $>80 \mathrm{~cm}$ ), followed by a large number of younger trees (DBH: 30-60 cm) (Fig. 1). Beech is also strongly represented by juvenile individuals and a large number of seedlings. All cohorts of oak and beech seem to be established naturally, which is exemplified by a strong spatial genetic structure observed in this stand (Sandurska et al., in preparation).

Plant material was sampled from three cohorts: 1) adults - trees with DBH $>25 \mathrm{~cm}$ (all individuals sampled); 2) juveniles - trees with $\mathrm{DBH}<20 \mathrm{~cm}$ (a sample of 300 individuals, only F. sylvatica; no juveniles for $Q$. robur); and 3) seedlings $-<30 \mathrm{~cm}$ tall (a sample of about 640 individuals within each species). Leaves from individuals were collected in August of 2013 and 2014. The numbers of individuals sampled in each cohort and species are presented in Tables 1 and 2.

DNA from dried leaves was isolated with GeneMATRIXPlant \& Fungi DNA Purification Kit (EURx, Poland). For Fagus sylvatica the set of 20 nuclear microsatellite markers: $F c 3$ (FcC00468), Fc5 (FcCOO730), Fc6 (FcC00927), Fc9 (FcC03095) (Ueno et al., 2009); csolfagus_05, csolfagus_06, csolfagus_19, csolfagus_29, csolfagus_31, concat14_A_O, DE576_A_O, DUKCT_A_O, DZ447_A_O, EEU75_A_O,EJV8T_A_O, EMILY_A_O, ERHBI_A_O (Lefevre et al., 2012); sfc_oŌ $\overline{3} 6$, fc_1143 (Äsuka et al., 2004); FS1_15 (Pastorelli et al., 2003) was used for genotyping of the samples. The Quercus robur genotyping was done by the set of 19 microsatellite markers: PIE-20, PIE102, PIE-215, PIE-223, PIE-242, PIE-243, PIE-267, ssrQrZAG 7, ssrQrZAG 11, ssrQrZAG 20, ssrQrZAG 96, ssrQpZAG 15, ssrQpZAG 110 (Guichoux et al., $2011 \mathrm{~b}$ ); ssrQrZAG 30, ssrQrZAG 65, ssrQrZAG 87, ssrQrZAG 101, ssrQrZAG 112 (Kampfer et al., 1998); ssrQpZAG 9 - modified (Steinkellner et al., 1997). PCR products were separated using the ABI PRISM 3130XL sequencer (Applied Biosystems, Foster City, USA). Allele identification was performed with GENESCAN 3.7 and GENOTYPER 3.7 software provided by Applied Biosystems.

Parameters of genetic structure were calculated using CERvus v3.0 (Kalinowski et al., 2007). Allelic richness was estimated using FsTAT 2.9.3.2 (Goudet, 1995). Differentiation measures $\left(F_{\mathrm{st}}, R_{\mathrm{st}}\right)$ between different cohorts were calculated using SPAGEDI v.1.5 (Hardy and Vekemans, 2002). The frequencies of null alleles and inbreeding coefficients accounting for the presence of null alleles and genotyping errors were calculated within each cohort using INEsT v.2.0 software (Chybicki and Burczyk, 2009). Effective population size $(\mathrm{Ne})$ was estimated for individual cohorts based on the linkage disequilibrium method (Waples and Do, 2008). The temporal method (Waples, 1989) for estimating Ne was also used employing pairs of different cohorts, based on Pollak's method for computing the standardized variance in allele frequency (Pollak, 1983). The estimates were calculated using NeEstimator v2 (Do et al., 2014); however, we screened out alleles with frequencies lower then $0.02\left(P_{\text {Crit }}=0.02\right)$ as suggested for microsatellite data (Do et al., 2014).

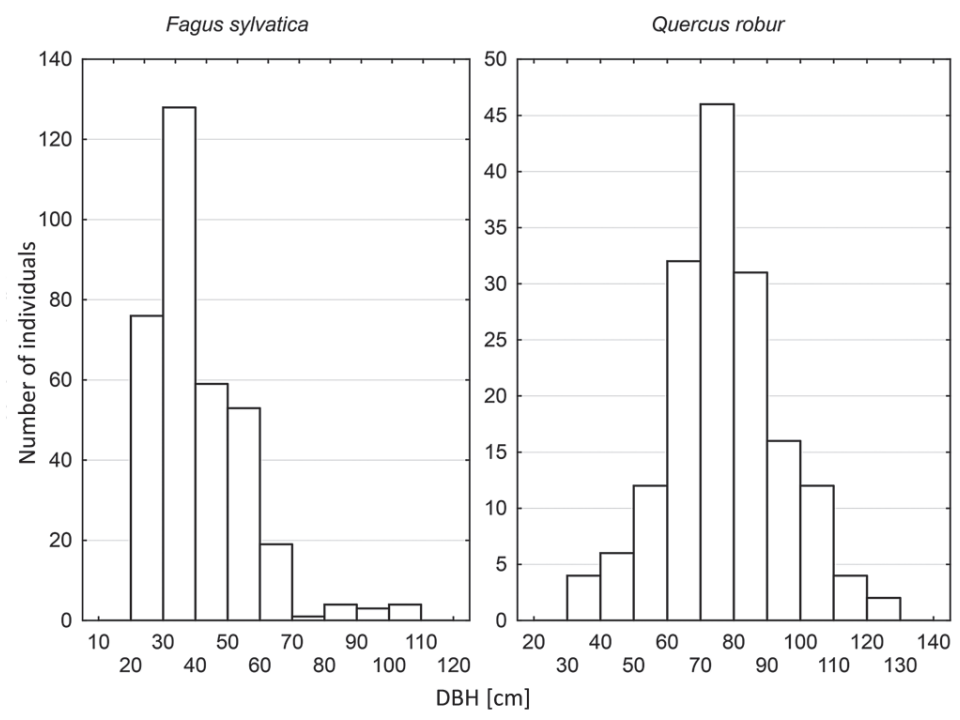

Fig. 1. The distribution of diameter at breast height $(\mathrm{DBH}$, in $\mathrm{cm})$ in adult populations of Fagus sylvatica and Quercus robur. 
TABLE 1. Genetic diversity of Fagus sylvatica in the reserve Jamy. Details for each locus are presented only for adult population, mean values are given for adults $(\mathrm{N}=333)$, juveniles $(\mathrm{N}=300)$ and seedlings $(\mathrm{N}=644)$. $(A)$ : mean number of alleles; (Ae): effective number of alleles; (AR): allelic richness; (Ho): observed heterozygosity; (He): expected heterozygosity; (Fis): inbreeding coefficient; (Null): frequency of null alleles; $(H-W)$ : significance of departure from Hardy-Weinberg equilibrium. Standard errors in parentheses.

\begin{tabular}{|c|c|c|c|c|c|c|c|c|}
\hline Locus & $A$ & $A e$ & $A R$ & Ho & $\mathrm{He}$ & Fis & Null & $H W$ \\
\hline Cf29 & 3 & 1.389 & 3.000 & 0.288 & 0.280 & -0.028 & 0 & ns \\
\hline Cf31 & 12 & 5.780 & 11.895 & 0.925 & 0.827 & -0.119 & 0 & $* * *$ \\
\hline Cf5 & 7 & 2.778 & 7.000 & 0.631 & 0.640 & 0.015 & 0.0047 & ns \\
\hline Cf6 & 11 & 5.682 & 10.789 & 0.859 & 0.824 & -0.042 & 0 & ns \\
\hline Concat & 4 & 1.437 & 4.000 & 0.276 & 0.304 & 0.09 & 0.0217 & ns \\
\hline Fc5 & 4 & 2.092 & 4.000 & 0.550 & 0.522 & -0.052 & 0 & ns \\
\hline Fc9 & 11 & 2.801 & 10.790 & 0.637 & 0.643 & 0.011 & 0.0086 & $\mathrm{~ns}$ \\
\hline Fs115 & 13 & 4.274 & 12.684 & 0.739 & 0.766 & 0.036 & 0 & ns \\
\hline Sfc0036 & 7 & 2.695 & 7.000 & 0.628 & 0.629 & 0.002 & 0.0005 & ns \\
\hline Sfc1143 & 14 & 5.650 & 13.846 & 0.801 & 0.823 & 0.026 & 0.0100 & ns \\
\hline Cf19 & 12 & 6.410 & 11.796 & 0.837 & 0.844 & 0.008 & 0 & ns \\
\hline De576 & 7 & 2.618 & 6.988 & 0.601 & 0.618 & 0.029 & 0.0011 & ns \\
\hline Dukct & 7 & 2.506 & 7.000 & 0.565 & 0.601 & 0.061 & 0.0132 & ns \\
\hline Dz447 & 5 & 2.123 & 4.895 & 0.541 & 0.529 & -0.021 & 0 & ns \\
\hline Ejv8t & 6 & 2.841 & 6.000 & 0.432 & 0.648 & 0.332 & $0.1360^{*}$ & $* * *$ \\
\hline Emily & 7 & 4.545 & 6.999 & 0.820 & 0.780 & -0.051 & 0 & ns \\
\hline Erhbi & 4 & 1.869 & 4.000 & 0.447 & 0.465 & 0.038 & 0.0222 & ns \\
\hline Fc3 & 11 & 4.587 & 10.884 & 0.784 & 0.782 & -0.002 & 0 & ns \\
\hline Fc6 & 12 & 5.076 & 11.903 & 0.815 & 0.803 & -0.015 & 0.0015 & ns \\
\hline Geu75 & 11 & 5.405 & 10.989 & 0.823 & 0.815 & -0.010 & 0 & ns \\
\hline Mean & 8.4 & 3.628 & 8.323 & 0.650 & 0.657 & 0.015 & 0.0110 & \\
\hline adults & $(0.782)$ & $(0.366)$ & $(0.767)$ & $(0.042)$ & $(0.038)$ & (0.019) & $(0.0068)$ & \\
\hline Mean & 8.5 & 3.629 & 8.498 & 0.656 & 0.659 & 0.007 & 0.0084 & \\
\hline saplings & $(0.724)$ & $(0.366)$ & $(0.723)$ & $(0.042)$ & $(0.037)$ & $(0.019)$ & $(0.0062)$ & \\
\hline Mean & 8.9 & 3.670 & 8.291 & 0.659 & 0.667 & 0.013 & 0.0110 & \\
\hline seedlinoss & $(0.757)$ & $(0.353)$ & $(0.684)$ & $(0.038)$ & $(0.036)$ & $(0.016)$ & $(0.0058)$ & \\
\hline
\end{tabular}

Significance: ${ }^{*} p<0.05 ;{ }^{* * *} p<0.001 ;$ ns - not significant at $p<0.05$

\section{RESULTS}

\section{GENETIC DIVERSITY}

All loci used in the analyses of beech were polymorphic with numbers of alleles per locus ranging from 3 to 14 (mean 8.4), however, the mean effective number of alleles was found to be 3.628. The observed and expected heterozygosities appeared to be quite similar (Table 1). The levels of null allele frequencies was low, in general. For adult and juvenile cohorts, only locus Ejv8t exhibited considerable and significant frequency of null alleles (Table 1), but in seedlings significant level of null alleles was observed additionally at Fs115 locus. Inbreeding was found to be low. It averaged across loci at $0.015,0.007$ and 0.013 for adults, juveniles and seedlings, respectively. Nevertheless, when accounting for the presence of null alleles, a low but significant level of inbreeding was observed only for seedlings $(0.0044 ; 95 \%$ CI: $0.0008-0.0083)$. The estimates of population genetic parameters were found to be similar across different cohorts, with a slight increase observed for seedlings.

All loci used for oak analyses were highly polymorphic, with 7 to 33 alleles per locus (17.89 on average) (Table 2). The effective number of alleles varied widely across loci from 2.92 to 21.23 . 
TABLE 2. Genetic diversity of Quercus robur in the reserve Jamy. Details for each locus are presented only for adult population, mean values are given for adults $(\mathrm{N}=163)$ and seedlings $(\mathrm{N}=647)$. $(A)$ : mean number of alleles; $($ Ae $)$ : effective number of alleles; $(A R)$ : allelic richness; $(H o)$ : observed heterozygosity; $(H e)$ : expected heterozygosity; ( $F$ is): inbreeding coefficient; (Null): frequency of null alleles; $(H-W)$ : significance of departure from Hardy-Weinberg equilibrium. Standard errors in parentheses.

\begin{tabular}{|c|c|c|c|c|c|c|c|c|}
\hline Locus & $A$ & $A e$ & $A R$ & Ho & $\mathrm{He}$ & Fis & Null & $H W$ \\
\hline Pie102 & 12 & 2.865 & 11.969 & 0.632 & 0.651 & 0.029 & 0.0216 & ns \\
\hline Pie20 & 11 & 4.115 & 10.968 & 0.693 & 0.757 & 0.084 & 0.0346 & ns \\
\hline Pie215 & 9 & 3.906 & 8.908 & 0.761 & 0.744 & -0.023 & 0 & $\mathrm{~ns}$ \\
\hline Pie223 & 8 & 4.098 & 7.969 & 0.730 & 0.756 & 0.035 & 0.0019 & $\mathrm{~ns}$ \\
\hline Pie242 & 13 & 6.024 & 12.938 & 0.804 & 0.834 & 0.036 & 0.0152 & $\mathrm{~ns}$ \\
\hline Pie243 & 7 & 2.924 & 7.000 & 0.620 & 0.658 & 0.058 & 0.0049 & ns \\
\hline Pie267 & 13 & 5.291 & 12.997 & 0.834 & 0.811 & -0.028 & 0 & $\mathrm{~ns}$ \\
\hline Zag65 & 29 & 21.277 & 29.000 & 0.899 & 0.953 & 0.057 & 0.0226 & $\mathrm{~ns}$ \\
\hline Zag11 & 29 & 9.524 & 28.962 & 0.800 & 0.895 & 0.106 & $0.0402 *$ & $\mathrm{~ns}$ \\
\hline Zag112 & 17 & 5.556 & 16.907 & 0.791 & 0.820 & 0.035 & 0 & $\mathrm{~ns}$ \\
\hline Zag20 & 20 & 7.634 & 19.813 & 0.810 & 0.869 & 0.068 & 0.0223 & $\mathrm{~ns}$ \\
\hline Zag30 & 33 & 14.925 & 32.876 & 0.883 & 0.933 & 0.053 & 0.0098 & $* *$ \\
\hline Zag9 & 13 & 6.849 & 12.908 & 0.853 & 0.854 & 0.002 & 0 & ns \\
\hline Zag96 & 21 & 4.082 & 20.907 & 0.675 & 0.755 & 0.106 & 0.0177 & ns \\
\hline Zag101 & 23 & 10.417 & 22.888 & 0.876 & 0.904 & 0.031 & 0.0155 & ns \\
\hline Zag110 & 26 & 4.000 & 25.812 & 0.755 & 0.750 & -0.006 & 0 & ns \\
\hline Zag15 & 14 & 4.219 & 13.997 & 0.755 & 0.763 & 0.010 & 0.0044 & $\mathrm{~ns}$ \\
\hline Zag7 & 20 & 16.129 & 19.939 & 0.859 & 0.938 & 0.084 & 0.0409* & ns \\
\hline Zag87 & 22 & 11.364 & 21.876 & 0.859 & 0.912 & 0.058 & 0.0179 & ns \\
\hline Mean & 17.894 & 7.642 & 17.823 & 0.784 & 0.821 & 0.042 & 0.0142 & \\
\hline adults & (1.767) & (1.173) & (1.761) & $(0.019)$ & $(0.021)$ & (0.009) & $(0.0032)$ & \\
\hline Mean & 20.158 & 6.599 & 17.128 & 0.759 & 0.803 & 0.056 & 0.0187 & \\
\hline seedlings & $(2.082)$ & $(0.911)$ & (1.654) & $(0.022)$ & $(0.021)$ & $(0.010)$ & $(0.0031)$ & \\
\hline
\end{tabular}

Significance: ${ }^{*} p<0.05 ;{ }^{* *} p<0.01 ;$ ns - not significant at $p<0.05$

Apparently, some loci with large numbers of alleles had relatively low effective numbers of alleles (e.g., Zag110, Zag96). Expected heterozygosity was higher than observed one, resulting in an increased level of fixation index. Interestingly, while the mean number of alleles was distinctly higher for seedlings, the effective number of alleles was higher for adults. Given that both types of heterozygosity were lower in seedlings, the increase of mean number of alleles in this cohort could result from new alleles observed in seedlings at low frequencies, likely as a result of background pollination. In general, the frequency of null alleles in oak was low, but on average it was slightly lower in adults (0.0142) than in seedlings (0.0187). In adults, significant levels of nulls were observed for two loci (Zag11, Zag7; Table 2); however, in seedlings, low but significant levels of null alleles were observed for most loci, except Pie102, Pie215, Pie242, Pie267, Zag30, Zag9, Zag101. The mean levels of inbreeding averaged across loci for adults and seedlings were equal to 0.042 and 0.056 , respectively (Table 2). However, the levels of inbreeding estimated when accounting for the presence of null alleles were found to be significant for adults (0.0235; 95\% CI: $0.0010-0.0401)$, as well as for seedlings $(0.0288 ; 95 \% \mathrm{CI}$ : 0.0219-0.0361).

\section{GENETIC DIFFERENTIATION AMONG COHORTS}

Genetic differences between different cohorts within species were generally low (Table 3); however, the level of differentiation between seedlings and adults was distinctly greater for oak than for beech across both estimated parameters $\left(F_{\mathrm{st}}\right.$ and $\left.R_{\mathrm{st}}\right)$. Within 
TABLE 3. Levels of genetic differences between pairs of populations representing different cohorts within each of the studied species.

\begin{tabular}{cll}
\hline \hline \multicolumn{1}{c}{ Population pair } & \multicolumn{1}{c}{$\boldsymbol{F}_{\text {st }}$} & \multicolumn{1}{c}{$\boldsymbol{R}_{\text {st }}$} \\
\hline $\begin{array}{c}\text { Fagus sylvatica } \\
\text { adults-seedlings }\end{array}$ & $0.00072^{*}$ & $0.00071 \mathrm{~ns}$ \\
adults-juveniles & $0.00052 \mathrm{~ns}$ & $0.00004 \mathrm{~ns}$ \\
$\quad$ juveniles-seedlins & $0.00206^{*}$ & $0.00193^{*}$ \\
\hline Quercus robur & & \\
adults-seedlings & $0.01282^{*}$ & $0.01918^{*}$ \\
\hline
\end{tabular}

Significance: ${ }^{*} p<0.05$; ns - not significant at $p<0.05$

beech, the smallest differentiation was observed between adults and juveniles, as well as between adults and seedlings (Table 3 ). The consistency between $F_{\text {st }}$ and $R_{\text {st }}$ suggests that genetic drift is the main reason for differentiation between the cohorts.

\section{EFFECTIVE POPULATION SIZE}

The estimates of effective population size (EPS) appeared to be significantly greater for beech than for oak (Table 4). However, while in beech the effective populations size of adults equaled only $35.74 \%$ of the sampled census size $(\mathrm{Ne} / \mathrm{N}=0.3574)$, in oak adults the effective population size was $49.26 \%$ of the number of sampled individuals. Considering seedlings, which were sampled at comparable quantities in both species, beech appeared to have the estimates of effective population size three times greater than oak (Table 4). Interestingly, in oak the temporal method applied to the generations of adults and seedlings provided the EPS estimates quite similar to those obtained based on single sample approach in seedlings, which crossvalidates generally low level of EPS in oak seedlings. Such similarity was not observed in beech. In beech, all possible pairs of generations used for the temporal method provided relatively high estimates of EPS. The lowest estimate, however still considerable (224.6), was observed for the pair of juveniles and seedlings, but it should be mentioned that the generation of juveniles is rather unlikely to be the parental generation of the studied seedlings. The high estimates of EPS obtained based on the temporal method in beech suggest a high similarity of gene pools among different beech cohorts.

\section{DISCUSSION}

Monitoring genetic diversity of populations with the aid of genetic markers may provide important insights into the current status of populations
TABLE 4. The estimates of effective populations size obtained based on single sample (linkage disequilibrium) and temporal methods. (95\% CI in parentheses).

\begin{tabular}{lcc}
\hline \hline & Fagus sylvatica & Quercus robur \\
\hline Single sample & & \\
$\quad$ Adults & $119.0(100.7-141.8)$ & $80.3(72.2-89.7)$ \\
Juveniles & $91.3(78.7-106.4)$ & - \\
Seedlings & $149.2(118.8-188.3)$ & $49.7(46.0-53.3)$ \\
\hline Temporal & & \\
Adults-seedlings & $716.3(413.4-1562.2)$ & $47.8(37.5-60.3)$ \\
Adults-juveniles & $801.3(382.0-3894.5)$ & - \\
$\quad$ Juveniles-seedlings & $224.6(144.2-359.9)$ & - \\
\hline
\end{tabular}

(Schwartz et al., 2007; Fussi et al., 2016). Forest management may affect genetic diversity (Rajendra et al., 2014) and several studies were focused on the effect of forest management on genetic diversity (Buiteveld et al., 2007; Piotti et al., 2013; Ratnam et al., 2014; Westergren et al., 2015). However, in order to monitor the impacts of forest management and climate changes on genetic diversity of forest trees, intact populations not affected by human activities are needed to serve as a reference autochthonous populations. Ultimately, the results of genetic diversity obtained in this study in adult populations (old-growth natural stand) may serve as a reference for future comparisons with managed populations.

Validated multiplexes of microsatellite loci developed for beech (Lefevre et al., 2012; Pluess and Maattanen, 2013) and oaks (Guichoux et al., 2011b) recently became available, and they might be considered standard sets of marker loci for population genetic studies of these species. Nevertheless, there were only a few studies employing these loci which could demonstrate their utility and robustness in the context of genotyping problems (e.g., the presence of null alleles) (Guichoux et al., 2011a) Here we found that both sets of microsatellite loci showed low and acceptable levels of null allele frequencies, and all of them (with the exception of Ejv8t locus in beech) might be efficiently used in population genetic surveys. However, when estimating inbreeding levels, which are sensitive to the presence of null alleles, we advise using appropriate tools for accounting for null alleles (Chybicki and Burczyk, 2009).

The loci optimized for beech have rarely been used so far (de Lafontaine et al., 2013; Gomory et al., 2015). At European scale, these loci were represented on average by 12.1 alleles per locus (de Lafontaine et al., 2013), while in this study we found on average only 8.125 alleles per locus. Similarly, 
the expected and observed heterozygosities were found to be 0.702 and 0.694 at European scale, but in our case they were smaller and equaled 0.650 and 0.638 , respectively. These differences might obviously result from the fact that we sampled only a single population, located in the north-eastern distribution limit, presumably in the front edge of an expanding population (Magri et al., 2006). However, similar levels of genetic diversity, as in our study, were found in other beech populations (Westergren et al., 2015; Kempf and Konnert, 2016).

The presence of null alleles is a common problem in beech (Paffetti et al., 2012; Gomory et al., 2015), particularly when estimating the levels of inbreeding (Chybicki and Burczyk, 2009). Elevated levels of inbreeding in beech were found in several studies (Vornam et al., 2004; Buiteveld et al., 2007; Paffetti et al., 2012), but in most cases it was a likely effect of the presence of null alleles. Other authors (Rajendra et al., 2014; Westergren et al., 2015; Kempf and Konnert, 2016) observed relatively low levels of inbreeding. Apparently, when $F_{\text {is }}$ is estimated along with accounting for the presence of null alleles, the levels of inbreeding in beech are usually found to be insignificant (Piotti et al., 2013; Pluess and Maattanen, 2013).

In the case of oaks, the recently proposed validated multiplexes of microsatellites were used mostly to study mating patterns (Lagache et al., 2014), interspecific hybridization processes (Lander et al., 2013) or species identification (Neophytou, 2013; Rellstab et al., 2016) rather than genetic diversity (Curtu et al., 2015; Moracho et al., 2016). Nevertheless, the levels of population genetic parameters found in our study were similar to those observed by other authors (Streiff et al., 1998; Cottrell et al., 2003; Curtu et al., 2015).

Investigating temporal changes of genetic diversity between adult and offspring populations is interesting in the context of population sustainability, and is of great importance for nature reserves. Recently, such studies have been conducted in beech (Westergren et al., 2015) and oak (Dering and Chybicki, 2012; Vranckx et al., 2014) forest stands. Westergren et al. (2015) reported for beech, that actual and effective numbers of alleles, as well as the levels of expected heterozygosity were not different between adult and saplings cohorts; however, they noted slight excess of inbreeding in the offspring, but the estimates were not adjusted for the presence of null alleles. Those results closely resemble the findings obtained in this study. Here, the uniformly high levels of genetic parameters across different life-stages suggest that the population probably attains the maximum available levels of genetic diversity (given the used marker set) and the gene pool of parental generation is transferred to offspring generation to a great extent. This is supported by the relatively high estimates of effective population size and low levels of genetic differentiation between adults and offspring.

Similarly, in pedunculate oak, Vranckx et al. (2014) found no difference between adults and seedlings based on various parameters of population genetic structure. Dering and Chybicki (2012) noticed increase or decrease of genetic diversity of naturally regenerated seedlings as compared to adult generations, depending on the population studied. They also found differences in $\mathrm{Ne}$ estimates (from 49 to 237), which corresponded well to the differentiation levels revealed by $F_{\text {st }}$ indices. Nevertheless, some of the mentioned studies (Vranckx et al., 2014; Westergren et al., 2015) were done based on relatively small numbers of adults and seedlings/saplings per population, making the detection of possible differences difficult. Also, the above mentioned studies focused only on singlespecies stands.

In this study we investigated genetic changes between parental and offspring generations in beech and oak populations coexisting in a mixed stand composed of the two species. The studied forest stand seems to be at the stage of transition from oak- to beech- dominated forest. Here, beech is well represented across various age classes and demonstrates successful regeneration. On the other hand, oak is represented only by an adult cohort and 1-3 years old seedlings, suggesting the decline of this population. Indeed, beech has the tendency to dominate the forest stands where it occurs, competing commonly with pedunculate oak (Packham et al., 2012).

The competitive advantage of beech may result from its shade tolerance (Ligot et al., 2013) and specific root development (Leuschner et al., 2001), but here we demonstrate that genetic diversity and the degree to which it is transferred from adults to offspring may also favor beech, as compared to oak. At first sight, oak shows greater genetic diversity than beech (Tables 1 and 2). However, genetic diversity measures such as expected heterozygosity or allelic richness depend on the selected genetic markers, therefore are not appropriate for comparisons between species. However, the estimates of inbreeding or effective population size are independent of the specific marker set and they are comparable across different species.

\section{CONCLUSIONS}

From a genetic point of view, beech population seems to perform very well in the studied stand: indices of genetic diversity were uniformly high across the cohorts, suggesting that the population reaches its maximum variability, given the set of 
used genetic markers. Additionally, the adult generation had no signs of inbreeding, there was no differentiation between adults and offspring, and effective population sizes were large. On the other hand, the oak population demonstrated some symptoms of decline. Adults and offspring showed significant levels of inbreeding. Notably, while the mean number of alleles increased from adults to the generation of seedlings, the effective number of alleles was decreasing. Genetic differentiation between adults and seedlings, as measured based on $F_{\mathrm{st}}$ and $R_{\mathrm{st}}$, was much greater than in beech. Finally, effective population sizes appeared to be low, which was particularly evident for seedlings. All these results suggest a restricted number of local oaks participating in reproduction.

Genetic diversity cannot be considered the major determinant of beech success or oak decline in the Jamy Nature Reserve. However, low inbreeding levels and high genetic diversity revealed by large effective population sizes may support beech as a successive species in the studied forest stand. From this point of view, no action needs to be taken to conserve genetic diversity of the beech population. However, the future of oak in the forest stand of the Jamy Reserve seems foregone. Given the reserve status of the studied stand, possible actions to be undertaken to protect genetic diversity of the oak population are limited to ex-situ conservation measures. In order to conserve the potentially valuable gene pool of the oak population, it is advised that seeds from as many as possible oak trees should be collected and used for establishing ex-situ plantations to preserve yet available gene diversity of oaks.

\section{AUTHORS' CONTRIBUTIONS}

$\mathrm{ES}, \mathrm{BU}$ and JB designed the research and wrote the article. ES and BU collected samples, genotyped plant material and contributed to statistical analyses. JB obtained funding.

\section{ACKNOWLEDGEMENTS}

The study was supported by the National Science Center (Grant No: 2012/04/A/NZ9/00500). Plant material was sampled based on the permission WPN.6205.42.2013.KLD issued by the Regional Directorate for Environmental Protection in Bydgoszcz, Poland. The authors are thankful to Katarzyna Meyza and Ewa Sztupecka for laboratory work and field assistance. Local support, field guidance and suggestions provided by Andrzej Tarnawski, Tadeusz Kempa and Stanislaw Milkowski from the Directorate of Forest District Jamy are greatly acknowledged.

\section{REFERENCES}

Aitken SN, Yeaman S, Holliday JA, Wang T, and CurtisMCLANE S. 2008. Adaptation, migration or extirpation: climate change outcomes for tree populations. Evolutionary Applications 1: 95-111.

AsUKa Y, TANi N, TSUMURA Y, and Tomaru N. 2004. Development and characterization of microsatellite markers for Fagus crenata Blume. Molecular Ecology Notes 4: 101-103.

Balmford A, Bruner A, Cooper P, Costanza R, Farber S, Green RE, Jenkins M, JefFeriss P, Jessamy V, MadDEN J, Munro K, Myers N, Naeem S, Paavola J, Rayment M, Rosendo S, Roughgarden J, TRumper K, and Turner RK. 2002. Economic reasons for conserving wild nature. Science 297: 950-953.

Bengtsson J, Angelstam P, Elmgvist T, Emanuelsson U, FolKe C, Ihse M, Moberg F, and Nystrom M. 2003. Reserves, resilience and dynamic landscapes. Ambio 32: 389-396.

Bolte A, and Degen B. 2010. Forest adaptation to climate change - options and limitations. Landbauforschung 60: 111-17.

Bontemps JD, Herve JC, Duplat P, and Dhote JF. 2012. Shifts in the height-related competitiveness of tree species following recent climate warming and implications for tree community composition: the case of common beech and sessile oak as predominant broadleaved species in Europe. Oikos 121: 1287-299.

Buiteveld J, Vendramin GG, Leonardi S, Kamer K, and GeBUREK T. 2007. Genetic diversity and differentiation in European beech (Fagus sylvatica L.) stands varying in management history. Forest Ecology and Management 247: 98-06.

Bussotti F, Pollastrini M, Holland V, and Bruggemann W. 2015. Functional traits and adaptive capacity of European forests to climate change. Environmental and Experimental Botany 111: 91-113.

CHYBICKI IJ, and BURCZYK J. 2009. Simultaneous estimation of null alleles and inbreeding coefficients. Journal of $\mathrm{He}$ redity 100: 106-113.

Cottrell Je, Munro RC, Tabbener he, Milner AD, ForREST GI, and LowE AJ. 2003. Comparison of fine-scale genetic structure using nuclear microsatellites within two British oakwoods differing in population history. Forest Ecology and Management 176: 287-303.

Curtu A, Craciunesc I, Enescu C, Vidalis A, and Sofletea N. 2015. Fine-scale spatial genetic structure in a multi-oakspecies (Quercus spp.) forest. iForest - Biogeosciences and Forestry 8: 324-332.

Czucz B, Galhidy L, and Matyas C. 2011. Present and forecasted xeric climatic limits of beech and sessile oak distribution at low altitudes in Central Europe. Annals of Forest Science 68: 99-108.

de Lafontaine G, Ducousso A, Lefevre S, Magnanou E, and PetiT RJ. 2013. Stronger spatial genetic structure in recolonized areas than in refugia in the European beech. Molecular Ecology 22: 4397-4412.

Dering M, and CHYBICKI I. 2012. Assessment of genetic diversity in two-species oak seed stands and their progeny populations. Scandinavian Journal of Forest Research 27: 2-9.

Do C, Waples RS, Peel D, Macbeth GM, Tillett BJ, and OvENDEN JR. 2014. NEESTIMATOR v2: re-implementation of 
software for the estimation of contemporary effective population size $(\mathrm{Ne})$ from genetic data. Molecular Ecology Resources 14: 209-214.

Frankham R. 2005. Genetics and extinction. Biological Conservation 126: 131-140.

Fussi B, Westergren M, Aravanopoulos F, Baier R, Kavaliauskas D, Finzgar D, Alizoti P, Bozic G, Avramidou E, Konnert M, and Kraigher H. 2016. Forest genetic monitoring: an overview of concepts and definitions. Environmental Monitoring and Assessment 188: 493.

GeBurek T, and TuroK J. 2005. Conservation and management of forest genetic resources in Europe. Arbora Publishers Zvolen.

Gessler A, Keitel C, Kreuzwieser J, Matyssek R, Seiler W, and Rennenberg H. 2006. Potential risks for European beech (Fagus sylvatica L.) in a changing climate. Trees 21: 1-11.

Gomory D, Ditmarova L, Hrivnak M, Jamnicka G, Kmet' J, KraJMEROVA D, and KURJAK D. 2015. Differentiation in phenological and physiological traits in European beech (Fagus sylvatica L.). European Journal of Forest Research 134: 1075-1085.

GoudET J. 1995. FSTAT (Version 1.2): A computer program to calculate F-statistics. Journal of Heredity 86: 485-486.

GRUMBine RE. 1994. What is ecosystem management? Conservation Biology 8: 27-38.

Gugerli F, Brandl R, Castagneyrol B, Franc A, Jactel H, Koelewijn HP, Martin F, Peter M, Pritsch K, SchroDer H, Smulders MJ, Kremer A, Ziegenhagen B, and Evoltree JC. 2013. Community genetics in the time of next-generation molecular technologies. Molecular Ecology 22: 3198-3207.

Guichoux E, Lagache L, Wagner S, Chaumeil P, Leger P, Lepais O, Lepoittevin C, Malausa T, Revardel E, Salin F, and Petit RJ. 2011a. Current trends in microsatellite genotyping. Molecular Ecol Resources 11: 591-611.

Guichoux E, Lagache L, Wagner S, Leger P, and Petit RJ. $2011 \mathrm{~b}$. Two highly validated multiplexes (12-plex and 8-plex) for species delimitation and parentage analysis in oaks (Quercus spp.). Molecular Ecology Resources 11: 578-585.

HARDY OJ, and VeKemans X. 2002. SPAGeDi: a versatile computer program to analyse spatial genetic structure at the individual or population levels. Molecular Ecology Notes 2: 618-620.

Hughes AR, Inouye BD, Johnson MT, Underwood N, and VelLEND M. 2008. Ecological consequences of genetic diversity. Ecology Letters 11: 609-623.

JANSEN S, and GEBUREK T. 2016. Historic translocations of European larch (Larix decidua Mill.) genetic resources across Europe - A review from the 17th until the mid20th century. Forest Ecology and Management 379: 114-123.

Kalinowski ST, TAPER ML, and MARShall TC. 2007. Revising how the computer program CERVUS accommodates genotyping error increases success in paternity assignment. Molecular Ecology 16: 1099-1106.

Kampfer S, Lexer C, Glössl J, and Steinkellner H. 1998. Characterization of (GA)n microsatellite loci from Quercus robur. Hereditas 129: 183-186.
KEMPF M, and KonNerT M. 2016. Distribution of genetic diversity in Fagus sylvatica at the north-eastern edge of the natural range. Silva Fennica 50(4) (in press).

Konig AO, Ziegenhagen B, van Dam BC, Csaikl UM, Coart E, Degen B, Burg K, De Vries SMG, and Petit RJ. 2002. Chloroplast DNA variation of oaks in western Central Europe and genetic consequences of human influences. Forest Ecology and Management 156: 147-166.

Koskela J, Buck A, and Teissier du Cros E. 2007. Climate change and forest genetic diversity: Implications for sustainable forest management in Europe. Bioversity International, Rome, Italy.

Koskela J, Vinceti B, Dvorak W, Bush D, Dawson IK, LOO J, Kuaer ED, Navarro C, Padolina C, Bordacs S, JamnaDASS R, GRAUDAL L, and RAMAMONJISOA L. 2014. Utilization and transfer of forest genetic resources: A global review. Forest Ecology and Management 333: 22-34.

Kramer K, Degen B, Buschbom J, Hickler T, Thuiller W, SyKES MT, and DE WINTER W. 2010. Modelling exploration of the future of European beech (Fagus sylvatica L.) under climate change-Range, abundance, genetic diversity and adaptive response. Forest Ecology and Management 259: 2213-2222.

Lagache L, Klein EK, Ducousso A, and Petit RJ. 2014. Distinct male reproductive strategies in two closely related oak species. Molecular Ecology 23: 4331-4343.

LANDE R, and SHANNON S. 1996. The role of genetic variation in adaptation and population persistence in a changing environment. Evolution 50: 434-437.

Lander TA, Klein EK, Stoeckel S, Mariette S, Musch B, and OdDOu-Muratorio S. 2013. Interpreting realized pollen flow in terms of pollinator travel paths and land-use resistance in heterogeneous landscapes. Landscape Ecology 28: 1769-1783.

Lefevre S, Wagner S, Petit RJ, and de Lafontaine G. 2012. Multiplexed microsatellite markers for genetic studies of beech. Molecular Ecology Resources 12: 484-491.

Leuschner C, Hertel D, Coners H, and Buttner V. 2001. Root competition between beech and oak: a hypothesis. Oecologia 126: 276-284.

Lewandowski A, Litkowiec M, Grygier A, and Dering M. 2012. Weryfikacja pochodzenia świerka pospolitego (Picea abies) w Nadleśnictwie Gołdap. Sylwan 156: 494-501.

Lewandowski A, Szydlarski M, and Litkowiec M. 2014. Pochodzenie świerka pospolitego (Picea abies (L.) Karst.) w Nadleśnictwie Kartuzy. Sylwan 158: 509-515.

Ligot G, Balandier P, Fayolle A, Lejeune P, and Claessens H. 2013. Height competition between Quercus petraea and Fagus sylvatica natural regeneration in mixed and uneven-aged stands. Forest Ecology and Management 304: 391-398.

Magri D, Vendramin GG, Comps B, Dupanloup I, Geburek T, GoMory D, Latalowa M, LitT T, Paule L, Roure JM, Tantau I, van der Knaap WO, Petit RJ, and de Beaulieu JL. 2006. A new scenario for the quaternary history of European beech populations: palaeobotanical evidence and genetic consequences. New Phytologist 171: 199-221.

Mette T, Dolos K, Meinardus C, Brauning A, Reineking B, Blaschke M, Pretzsch H, Beierkuhnlein C, Gohlke A, and WeLlstein C. 2013. Climatic turning point for beech and oak under climate change in Central Europe. Ecosphere 4: 1-19. 
Moracho E, Moreno G, Jordano P, and Hampe A. 2016. Unusually limited pollen dispersal and connectivity of Pedunculate oak (Quercus robur) refugial populations at the species' southern range margin. Molecular Ecology 25: 3319-3331.

Myking T, Rusanen M, Steffenrem A, KJÆr ED, and Jansson G. 2016. Historic transfer of forest reproductive material in the Nordic region: drivers, scale and implications. Forestry (in press).

Neophytou C. 2013. Bayesian clustering analyses for genetic assignment and study of hybridization in oaks: effects of asymmetric phylogenies and asymmetric sampling schemes. Tree Genetics and Genomes 10: 273-285.

Packham JR, Thomas PA, Atkinson MD, and Degen T. 2012. Biological Flora of the British Isles: Fagus sylvatica. Journal of Ecology 100: 1557-1608.

Paffetti D, Travaglini D, Buonamici A, Nocentini S, Vendramin GG, Giannini R, and Vettori C. 2012. The influence of forest management on beech (Fagus sylvatica L.) stand structure and genetic diversity. Forest Ecology and Management 284: 34-44.

Pastorelli R, Smulders MJM, Van't Westende WPC, Vosman B, Giannini R, Vettori C, and Vendramin GG. 2003. Characterization of microsatellite markers in Fagus sylvatica L. and Fagus orientalis Lipsky. Molecular Ecology Notes 3: 76-78.

Petritan IC, Marzano R, Petritan AM, and Lingua E. 2014. Overstory succession in a mixed Quercus petraea-Fagus sylvatica old growth forest revealed through the spatial pattern of competition and mortality. Forest Ecology and Management 326: 9-17.

Piotti A, Leonardi S, Heuertz M, Buiteveld J, Geburek T, GerBer S, Kramer K, Vettori C, and Vendramin GG. 2013. Within-population genetic structure in beech (Fagus sylvatica L.) stands characterized by different disturbance histories: does forest management simplify population substructure? PLoS One 8: e73391.

Pluess AR, and MaAtTanen K. 2013. Characterization of eighteen novel microsatellite markers and multiplex PCR protocol for Fagus sylvatica. Conservation Genetics Resources 5: 311-314.

POLLAK E. 1983. A new method for estimating the effective population size from allele frequency changes. Genetics 104: 531-548.

Prendergast JR, Quinn RM, and Lawton JH. 1999. The gaps between theory and practice in selecting nature reserves. Conservation Biology 13: 484-492.

Pretzisch H, Bielak K, Block J, Bruchwald A, Dieler J, EhRhart HP, Kohnle U, Nagel J, Spellmann H, Zasada M, and ZINGG A. 2013. Productivity of mixed versus pure stands of oak (Quercus petraea (Matt.) Liebl. and Quercus robur L.) and European beech (Fagus sylvatica L.) along an ecological gradient. European Journal of Forest Research 132: 263-280.

Rajendra KC, Seifert S, Prinz K, Gailing O, and Finkeldey R. 2014. Subtle human impacts on neutral genetic diversity and spatial patterns of genetic variation in European beech (Fagus sylvatica). Forest Ecology and Management 319: 138-149.

Ratnam W, Rajora OP, Finkeldey R, Aravanopoulos F, BouVET JM, Vaillancourt RE, Kanashiro M, FAdy B, TOMITA M, and VINSON C. 2014. Genetic effects of forest man- agement practices: Global synthesis and perspectives. Forest Ecology and Management 333: 52-65.

Rellstab C, Bühler A, GraF R, Folly C, and Gugerli F. 2016. Using joint multivariate analyses of leaf morphology and molecular-genetic markers for taxon identification in three hybridizing European white oak species (Quercus spp.). Annals of Forest Science 73: 669-679.

Rohner B, Bigler C, Wunder J, Brang P, and Bugmann H. 2012. Fifty years of natural succession in Swiss forest reserves: changes in stand structure and mortality rates of oak and beech. Journal of Vegetation Science 23: 892-905.

Scharnweber T, Manthey M, Criegee C, Bauwe A, Schroder C, and WiLMking M. 2011. Drought matters - Declining precipitation influences growth of Fagus sylvatica L. and Quercus robur L. in north-eastern Germany. Forest Ecology and Management 262: 947-961.

Schwartz MK, LuikarT G, and Waples RS. 2007. Genetic monitoring as a promising tool for conservation and management. Trends in Ecology and Evolution 22: 25-33.

SoulÉ ME. 1985. What is conservation biology? A new synthetic discipline addresses the dynamics and problems of perturbed species, communities, and ecosystems. BioScience 35: 727-34.

Spielman D, BRoOK BW, and Frankham R. 2004. Most species are not driven to extinction before genetic factors impact them. PNAS 101: 15261-15264.

Steinkellner H, Fluch S, Turetschek E, Lexer C, Streiff R, Kremer A, Burg K, and GlÖSsL J. 1997. Identification and characterization of $(\mathrm{GA} / \mathrm{CT}) \mathrm{n}$ - microsatellite loci from Quercus petraea. Plant Molecular Biology 33: 1093-1096.

Streiff R, Labbe T, Bacilieri R, Steinkellner H, Glossl J, and KREMER A. 1998. Within-population genetic structure in Quercus robur L. and Quercus petraea (Matt.) Liebl. assessed with isozymes and microsatellites. Molecular Ecology 7: 317-328.

Ueno S, Taguchi Y, Tomaru N, and Tsumura Y. 2009. Development of EST-SSR markers from an inner bark cDNA library of Fagus crenata (Fagaceae). Conservation Genetics 10: 1477-1485.

VERA FWM, BAKKeR ES, and OlfF H. 2006. Large herbivores: missing partners of western European light-demanding tree and shrub species? In: Danell K, Bergström R, Duncan P, Pastor J. (eds.), Large Herbivore Ecology, Ecosystem Dynamics and Conservation, 203-231, Cambridge University Press, Cambridge.

Vornam B, Decarli N, and Gailing O. 2004. Spatial distribution of genetic variation in a natural beech stand (Fagus sylvatica L.) based on microsatellite markers. Conservation Genetics 5: 561-570.

Vranckx G, Jacguemyn H, Mergeay J, Cox K, Kint V, Muys B, and Honnay O. 2014. Transmission of genetic variation from the adult generation to naturally established seedling cohorts in small forest stands of pedunculate oak (Quercus robur L.). Forest Ecology and Management 312: 19-27.

WAPLES RS. 1989. A generalized approach for estimating effective population size from temporal changes in allele frequency. Genetics 121: 379-391.

WAPLES RS, and Do C. 2008. ldne: a program for estimating effective population size from data on linkage disequilibrium. Molecular Ecology Resources 8: 753-756. 
Westergren M, Bozic G, Ferreira A, and Kraigher H. 2015. Insignificant effect of management using irregular shelterwood system on the genetic diversity of European beech (Fagus sylvatica L.): A case study of managed stand and old growth forest in Slovenia. Forest Ecology and Management 335: 51-59.

Whitham TG, Bailey JK, Schweitzer JA, Shuster SM, Bangert RK, LeRoy CJ, Lonsdorf EV, Allan GJ, DIFAZIO SP, PotTs BM, Fischer DG, Gehring CA, LiNDRoth RL, Marks JC, HaRT SC, Wimp GM, and Wooley SC. 2006. A framework for community and ecosystem genetics: from genes to ecosystems. Nature Review Genetics 7: 510-523.

Whitham TG, Young WP, Martinsen GD, Gehring CA, SchWeitzer JA, SHuster SM, Wimp GM, Fischer DG, BAILEY JK, LindROTH RL, WoOlbright S, and Kuske CR. 2003. Community and ecosystem genetics: A consequence of the extended phenotype. Ecology 84: 559-573.

Zimmermann J, Hauck M, Dulamsuren C, and Leuschner C. 2015. Climate warming-related growth decline affects Fagus sylvatica, but not other broad-leaved tree species in central european mixed forests. Ecosystems 18: 560-572. 